\title{
What is the influence of ordinary epidermal cells and stomata on the leaf plasticity of coffee plants grown under full-sun and shady conditions?
}

\author{
Pompelli, MF. ${ }^{\mathrm{a}}$, Martins, SCV. ${ }^{\mathrm{b}}$, Celin, EF. ${ }^{\mathrm{b}}$ Ventrella, MC. ${ }^{\mathrm{b}}$ and DaMatta, FM. ${ }^{\mathrm{b}}$ \\ ${ }^{a}$ Laboratório de Ecofisiologia Vegetal, Departamento de Botânica, Centro de Ciências Biológicas - CCB, \\ Universidade Federal de Pernambuco - UFPE, Av. Prof. Moraes Rego, s.n., \\ Cidade Universitária, CEP 50670-901, Recife, PE, Brazil \\ ${ }^{\text {b} D e p a r t a m e n t o ~ d e ~ B i o l o g i a ~ V e g e t a l, ~ C e n t r o ~ d e ~ C i e ̂ n c i a s ~ B i o l o ́ g i c a s ~-~ C C B, ~}$ \\ Universidade Federal de Viçosa - UFV, CEP 36570-000, Viçosa, MG, Brazil \\ *e-mail: mpompelli@yahoo.com.br
}

Received July 16, 2009 - Accepted October 13, 2009 - Distributed November 30, 2010

(With 2 figures)

\begin{abstract}
Stomata are crucial in land plant productivity and survival. In general, with lower irradiance, stomatal and epidermal cell frequency per unit leaf area decreases, whereas guard-cell length or width increases. Nevertheless, the stomatal index is accepted as remaining constant. The aim of this paper to study the influence of ordinary epidermal cells and stomata on leaf plasticity and the influence of these characteristics on stomata density, index, and sizes, in the total number of stomata, as well as the detailed distribution of stomata on a leaf blade. As a result, a highly significant positive correlation $\left(\mathrm{R}_{\mathrm{a}}^{2}=0.767 \mathrm{p} \leq 0.001\right)$ between stomatal index and stomatal density, and with ordinary epidermal cell density $\left(\mathrm{R}_{\mathrm{a}}^{2}=0.500 \mathrm{p} \leq 0.05\right)$, and a highly negative correlation between stomatal index and ordinary epidermal cell area $\left(\mathrm{R}_{\mathrm{a}}^{2}=-0.571 \mathrm{p} \leq 0.001\right)$, were obtained. However in no instance was the correlation between stomatal index or stomatal density and stomatal dimensions taken into consideration. The study also indicated that in coffee, the stomatal index was $19.09 \%$ in shaded leaves and $20.08 \%$ in full-sun leaves. In this sense, variations in the stomatal index by irradiance, its causes and the consequences on plant physiology were discussed.
\end{abstract}

Keywords: stomatal index, stomatal density, sun and shade plants, Coffea arabica L.

\section{Qual a influência das células epidérmicas ordinárias e dos estômatos na plasticidade foliar de cafeeiros desenvolvidos a pleno sol e sob condições de sombra?}

\begin{abstract}
Resumo
Os estômatos são fundamentais na fisiologia vegetal e na sobrevivência das plantas. Em geral, com a diminuição da irradiância, a frequência estomática, ou mesmo epidérmica, por unidade de área foliar diminui, enquanto as dimensões dos estômatos aumentam. Por outro lado, acredita-se que o índice estomático, sendo uma característica intrínseca da planta, permanece constante. O objetivo deste trabalho foi estudar a influência das células epidérmicas ordinárias e das células estomáticas na plasticidade da folha e as influências destas características sobre a densidade e no índice estomático, bem como nas dimensões e no número de estômatos e descrever, em detalhes, os principais fatores que os alteram. Verificou-se, neste trabalho, uma correlação fortemente significativa $\left(R_{a}^{2}=0,767 \mathrm{p} \leq 0,001\right)$ entre o índice estomático e a densidade estomática, ou mesmo, entre este e a densidade de células epidérmicas $\left(\mathrm{R}_{\mathrm{a}}^{2}=0,500 \mathrm{p} \leq 0,05\right)$. Uma forte correlação negativa entre o índice estomático e a área das células epidérmicas $\left(\mathrm{R}_{\mathrm{a}}^{2}=-0,571 \mathrm{p} \leq 0,001\right)$ também foi verificada, entretanto, nenhuma correlação foi verificada entre o índice estomático e as dimensões dos estômatos, assim como sugere a literatura. De qualquer modo, este estudo demonstrou que o índice estomático do cafeeiro é de $19,09 \%$ nas folhas sombreadas e de 20,08\% nas folhas a pleno sol. Neste sentido, as variações no índice estomático causadas pela irradiância, suas causas e consequências para a fisiologia vegetal são discutidas em detalhes.
\end{abstract}

Palavras-chave: índice estomático, densidade estomática, plantas de sol e sombra, Coffea arabica L. 


\section{Introduction}

Light is a prime factor affecting both the growth and distribution of tissues in the whole plant (Fahn, 1990). Photosynthetic irradiance acclimation involves a variety of responses, including changes in leaf anatomical, morphological, biochemical and photosynthetic characteristics. There is a close relationship between leaf characteristics and the mean irradiance leaves are submitted to. Hence, irradiance distribution can be used for predicting spatial variation of leaf properties (Pandey et al., 2003 and references therein). In general, plants develop 'sun' or 'shade' leaves when acclimating to different irradiance levels. The anatomical and physiological differences between sun and shade leaves have been studied extensively. Anatomically, sun leaves have a more developed palisade tissue and a larger mesophyll surface area per unit leaf area (SLA), besides being thicker than shade leaves (Fahn, 1990).

Various types of epidermal cells can be distinguished in different plants: the ordinary epidermal cells, guard cells, subsidiary cells, trichomes and various idioblasts (Dickinson, 2000). Ordinary epidermal cells are basically the cells that lie between the more specialised cells of the epidermis, and they are typically the most numerous and cover the greatest proportion of the plant body (Mauseth, 1988). Guard-cells, together with the opening between then, constitute the stomata. In many plants, ordinary or accessory epidermal cells can be distinguished. These cells differ morphologically from the typical epidermal cells and they constitute two or more cells bordering the guard cells to which they are apparently functionally connected (Fahn, 1990). In this instance, stomata, together with these ordinary epidermal cells, if present, are termed the stomatal complex (Fahn, 1990). The ordinary cells usually develop from sister cells of the mother cells (DeBary, 1877). In plants, stomata play a major role in gas exchange and transpiration. Much information is available regarding both their physiology and the factors that affect the stomatal aperture. The relationship of ABA to closing of the stomata, and the corresponding physiology thereof, has received wide attention. Nevertheless, less consideration has been given to the effects of light on the development of the stomata and other epidermal cells and on stomata density itself.

Among the various stomatal characters, stomatal density (SD) is an important eco-physiological parameter that affects gas exchange and photosynthesis. The response of SD to environmental conditions has been an interesting and enduring question ever since the early observations of Woodward (1987) and others. Changes in several environmental parameters are thought to affect stomatal development. Light intensity (Lake et al., 2001), light quality (Schoch et al., 1980), humidity (Serna and Fenoli, 2000), UV-B radiation (Kakani et al., 2003), drought signals (Franks and Farquhar, 2001), ozone (Warren et al., 2006), atmospheric $\mathrm{CO}_{2}$ (Woodward, 1998) and elevated $\mathrm{CO}_{2}$ concentrations (Woodward and Kelly, 1995), have all been shown to affect stomatal density and/or the stomatal index. Stomatal density is determined by stomatal initiation during ontogenesis and by epidermal cell expansion at a later stage (Salisbury, 1927), although it is not clearly understood how stomatal density is controlled during leaf growth (Bergmann, 2004). It is believed that the stomatal index (SI) does not vary so much as SD, the first being so intrinsic to the species (Salisbury, 1927). However, we question the invariability of SI, since certain studies have shown the opposite (Lake et al., 2001; Liao et al., 2005; Miyazawa et al., 2006; Pandey et al., 2003; Zhao et al., 2006). In this study, we assessed the effect of environmental light on the leaf anatomy and plasticity of coffee plants, and enumerated the interference factors in leaf acclimation, specifically on stomata and epidermal structures.

\section{Material and Methods}

\subsection{Plant material and growth conditions}

The experiments were carried out with coffee plants (Coffea arabica L. cv red catuai IAC 44), between November, 2005 and March, 2006, in Viçosa (2045'S, 42 ${ }^{\circ} 54^{\prime} \mathrm{W}$, $650 \mathrm{~m}$ asl) Brazil. Two-month-old seedlings were planted in 12 litre pots containing soil and sand (2:1, v/v). The soil was kept moist through periodic irrigations. The experiments consisted of comparing two groups of plants, the first growing in full-sun, and the second group under shady conditions (ca. $50 \%$ of reduction in solar irradiation). Both were irrigated with a full-strength Hoagland solution (Epstein, 1972).

\subsection{Morphology measurements}

Four months after planting, the leaf area, leaf number and SLA were measured with a Genius 1200XE scanner (KYE Systems UK Ltd., Croydon, Surrey, UK). Speculate images were analysed by Image-Pro ${ }^{\circledR}$ Plus software (version 4.1, Media Cybernetics, Inc., Silver Spring, USA). Leaves were dried in a hot air oven at $70^{\circ} \mathrm{C}$ at a constant weight. SLA was calculated and expressed as $\mathrm{m}^{2} \mathrm{~kg}^{-1}$.

\subsection{Stomatal density and index, epidermal cell density and size}

A fully expanded fourth leaf from the apex of each plant was sampled for taking stomatal counts. The leaves were fixed and stored as previously described in Melo de Pinna et al. (2002). Five samples of each treatment at the mid-lamina region (areas in the vicinity of large veins were avoided) were treated with chloroform for 2 hours, by shaking, and then rinsed in ethanol $70 \%$ and tap water. The fragments were treated in sequence, first with a $10 \%$ $\mathrm{NaOH}$ solution for 2 hours, also by shaking, and then a $10 \% \mathrm{NaOCl}$ solution until complete tissue clarification (modified from Johansen, 1940). After rinsing well, the fragments were stained with a $1 \%$ crystal violet solution for 48 hours and then rinsed in tap water and ethanol $50 \%$ until the complete removal of excess stain. After being dehydrated in a graded ethanol and xilol series, the fragments were mounted on glass slides with a synthetic resin $\left(\right.$ Permount ${ }^{\circledR}$ ). Stomatal counts were done in 20 
randomly chosen microscopic fields from each fragment. Each field consisted of $0.171 \mathrm{~mm}^{2}$ at $20 \times$ magnification. A total of 100 fields were used in defining either the stomatal frequency or index. The number of stomata per field was converted to the number of stomata $\mathrm{mm}^{-2}$. SI was estimated as $(S /(E+S)) \times 100$, where $S$ is the number of stomata and $\mathrm{E}$ is the number of epidermal cells per unit leaf area (Salisbury, 1927). Stomatal complex areas (SC) were determined by measuring 60 random stomata as shown in Figure 1. The stomatal area (SA) was calculated as $\mathrm{SA}=\pi$ $\times(\mathrm{SW} / 2) \times(\mathrm{SL} / 2)$, where $\mathrm{SW}$ and SL are stomatal width and length (Figure 1). Ordinary epidermal cell area (OA) was calculated by the ratio between total fragment area minus stomatal complex area and ordinary epidermal cell number. Ordinary epidermal cell density (OD) was calculated in twenty fields. (Johansen, 1940; Melo de Pinna et al., 2002)

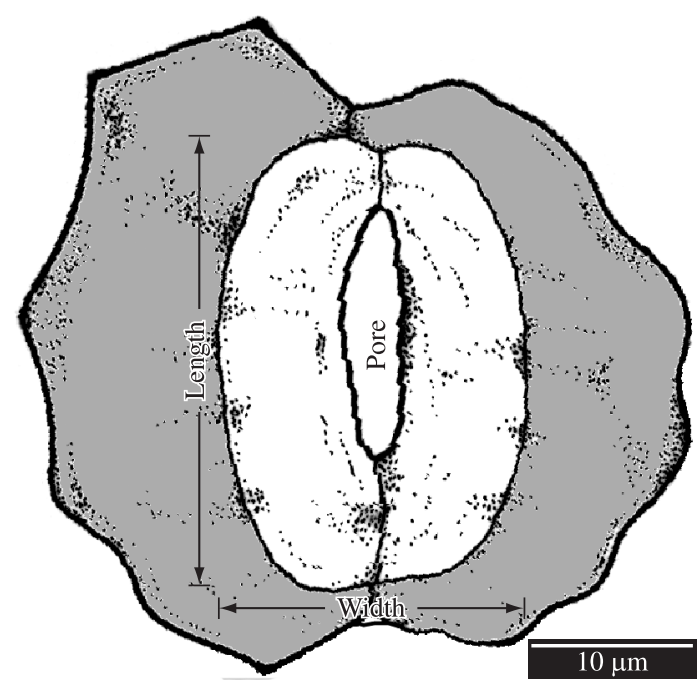

Figure 1. Stomatal complexes with stomatal dimensions (width and length) in evidence. Subsidiary cells are marked in grey.

\subsection{Leaf thickness}

To determine leaf thickness, five fragments fixed in FAA $_{50}$ were included in 2-hydroxyethyl-methacrylate (Leica Microsystems Nussloch, GmbH, Heibelberg, Germany), sectioned at $7 \mu \mathrm{m}$ and stained with toluidine blue. All measurements were made using a microscope connected to a computer and speculate image analysing program Image Pro ${ }^{\circledR}$ Plus version 4.1 (Media Cybernetics, Inc., Silver Spring, USA).

\subsection{Statistical analysis}

Results were analysed by a mixed-model ANOVA and means by the Newman-Keuls test using Statgraphics Plus Version 5.1 (StatPoint, Inc., Herndon, Virginia, USA). Correlation coefficients were calculated by Statistica 7.0 (StatSoft, Inc., Tulsa, Oklahoma, USA).

\section{Results}

Individual leaf area (LA), SLA, and OA decreased significantly $(\mathrm{P} \leq 0.001)$ in full-sun plants, whereas $\mathrm{SD}$, $\mathrm{OD}$, and SI increased significantly $(\mathrm{P} \leq 0.01$ and 0.001 ; Table 1). Stomata characteristics (e.g. stomatal dimensions and area) did not differ significantly in either of the full-sun or shade treatments. The leaves were smaller in full-sun than in the shade plantlets, this difference being connected with the smaller size of ordinary epidermal cells. In the present study, leaves developed under shady conditions presented an individual leaf area of $0.56 \mathrm{dm}^{2}$ whereas under full-sun conditions the individual leaf area was $0.41 \mathrm{dm}^{2}$, a $37 \%$ increase. Similar results were observed for SLA, whereby plants developed under full-sun and shady conditions resulted in 12.35 and $14.66 \mathrm{~m}^{2} \mathrm{~kg}^{-1}$ respectively, an increase of $19 \%$.

Exposure of the plants to different sun conditions, there was a significant $(\mathrm{P} \leq 0.01$ and 0.001$)$ increase in stomatal density, in stomatal index, and ordinary cell density in fullsun compared to shaded plants. On considering these three parameters, the average increases for plants grown under

Table 1. Stomatal and ordinary epidermal cell features and leaf parameters in coffee plants grown under full-sun or shady conditions. Means following the superscript $*$ or $* *$ showed significant differences at $\mathrm{P} \leq 0.01$ and $\mathrm{P} \leq 0.001$, between shaded and full-sun plants respectively. Means followed by $n s$ do not represent significance differences at $\mathrm{P} \geq 0.05$.

\begin{tabular}{lcr}
\hline Leaf and stomatal parameters & Shaded plants & Full-sun plants \\
\hline Individual leaf area $\left(\mathrm{m}^{2}\right)$ & $0.56 \pm 0.02^{* *}$ & $0.41 \pm 0.01^{* *}$ \\
Specific leaf area $\left(\mathrm{m}^{2} \mathrm{~kg}^{-1}\right)$ & $14.66 \pm 0.30^{* *}$ & $12.35 \pm 0.33^{* *}$ \\
Stomatal density $\left(\mathrm{mm}^{2}\right)$ & $138.84 \pm 4.57^{* *}$ & $184.42 \pm 3.59^{* *}$ \\
Stomatal index $(\%)$ & $19.09 \pm 0.28^{*}$ & $20.08 \pm 0.23^{*}$ \\
Ordinary cell density $\left(\mathrm{mm}^{2}\right)$ & $587.86 \pm 13.11^{* *}$ & $733.65 \pm 7.95^{* *}$ \\
Stomatal width $(\mu \mathrm{m})$ & $26.89 \pm 0.23^{\mathrm{ns}}$ & $26.80 \pm 0.18^{\mathrm{ns}}$ \\
Stomatal length $(\mu \mathrm{m})$ & $17.85 \pm 0.16^{\mathrm{ns}}$ & $17.79 \pm 0.10^{\mathrm{ns}}$ \\
Stomatal area $\left(\mu \mathrm{m}^{2}\right)$ & $377.24 \pm 5.25^{\mathrm{ns}}$ & $374.72 \pm 3.81^{\mathrm{ns}}$ \\
Stomatal complex area $\left(\mu \mathrm{m}^{2}\right)$ & $1137.94 \pm 24.02^{\mathrm{ns}}$ & $1136.46 \pm 36.14^{\mathrm{ns}}$ \\
Ordinary cell area $\left(\mu \mathrm{m}^{2}\right)$ & $1437.24 \pm 26.75^{* *}$ & $1069.09 \pm 21.79^{* *}$ \\
Leaf thickness $(\mu \mathrm{m})$ & $252.7 \pm 5.58^{\mathrm{ns}}$ & $262.1 \pm 5.83^{\mathrm{ns}}$ \\
\hline
\end{tabular}


full-sun conditions were $25 \%, 5 \%$, and $20 \%$, respectively (Table 1). The increase in these characteristics was caused by a reduction in ordinary cells area (ca. 26\%), although there were no modifications in any other stomatal attribute. Differences in individual stomatal size (guard-cell complex including the pore) were not recorded among the treatments. The average number of stomata per $\mathrm{mm}^{2}$ under full-sun was
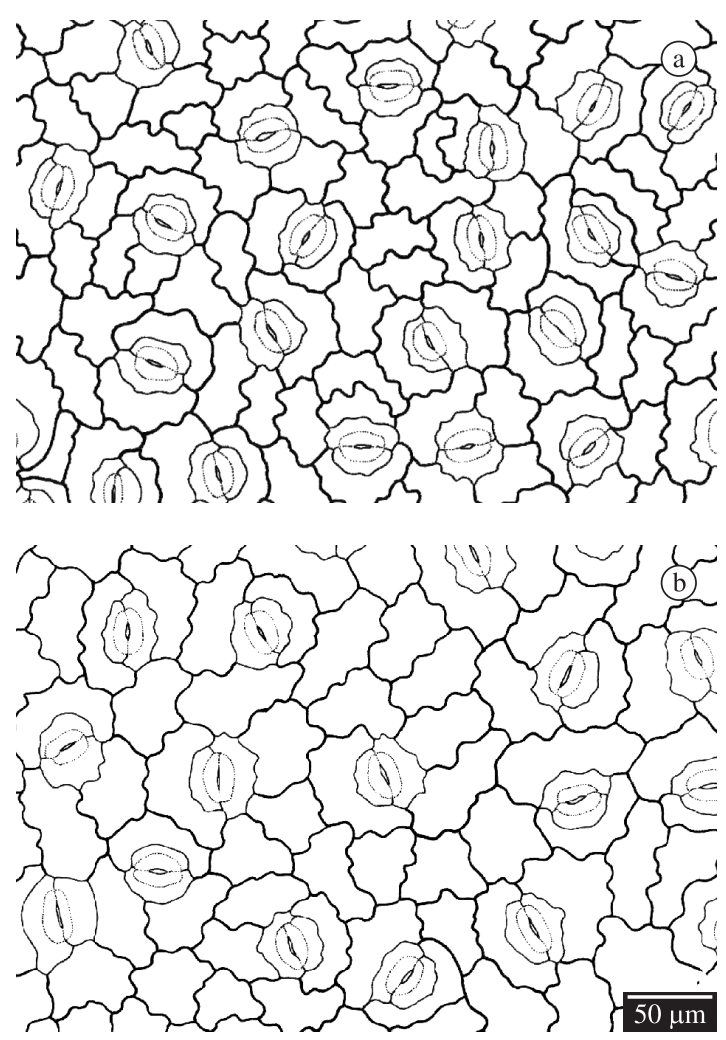

Figure 2. Epidermis abaxial surfaces in coffee plants grown under a) full-sun or b) shady conditions. significantly $(\mathrm{P} \leq 0.001)$ higher (184.42) than under shady conditions (138.84) (Table 1). A significantly lower number of stomata per leaf were also evident in full-sun plantlets, probably due to the smaller size of individual leaves. The epidermis structure in full-sun or shade plants is presented in Figure 2. The differences in SD and SI were a result of greater extension in ordinary epidermal dimensions than in stomatal dimensions. From correlation studies among stomatal parameters (Table 2), it was evident that there was a significant $(\mathrm{P} \leq 0.05$ and 0.001$)$ positive correlation of stomatal density with the stomatal index $\left(\mathrm{R}^{2}=0.767\right)$, and ordinary cell density $\left(\mathrm{R}^{2}=0.937\right)$, whereas a negative correlation was observed with the stomatal area $\left(R^{2}=-0.956\right)$. As regards the stomatal index, results were similar to those observed with stomatal density with a significant $(\mathrm{P} \leq 0.05)$ positive correlation with ordinary cell density $\left(\mathrm{R}_{\mathrm{a}}^{2}=0.500\right)$, and a slight negative correlation with leaf area $\left(\mathrm{R}^{2}{ }_{\mathrm{a}}=-0.423\right)$ and ordinary cell area $\left(\mathrm{R}^{2}{ }_{\mathrm{a}}=-0.571\right)$. In this work, no correlation was observed in SD or SI with stomatal dimension.

\section{Discussion}

The fundamental purpose of leaves is harvesting light. Under full-sun conditions, the photosynthetic capacity per unit leaf area increases, this resulting in increased thickness in leaves, accompanied by the production of an additional layer of palisade cells. Nevertheless, in the present study the effect of light conditions on mesophyll thickness was not observed (Table 1), contrary to what was previously reported for the Coffea genus (Fahl et al., 1994), but in accordance to Rahim and Fordham (1991) in garlic, and Onwueme and Johnston (2000) in Tannia, sweet potato, yam, cassava and taro. This difference might be due to intra-specific genetic makeup. It is generally assumed that shade leaves are thin and large, having a lower SD than that found in sun-exposed leaves (Fahn, 1990). In the present work plants grown under full-sun conditions, show

Table 2. Coefficients of correlations $\left(\mathrm{R}_{\mathrm{a}}^{2}\right)$ between stomatal and ordinary cell features in coffee plants (Coffea arabica) grown under full-sun or shady conditions. SI = stomatal index, LA = leaf area, SLA = specific leaf area, SD = stomatal density, $\mathrm{OD}=$ ordinary cell density, $\mathrm{SL}=$ stomatal length, $\mathrm{SW}=$ stomatal width, $\mathrm{SA}=$ stomatal area, $\mathrm{SC}=$ stomatal complex area, $\mathrm{OA}=$ ordinary cell area, $\mathrm{LT}=$ leaf thickness. Values followed by $*$, **, and $* * *$, represent significance differences at $\mathrm{P} \leq 0.05, \mathrm{P} \leq 0.01$, and $\mathrm{P} \leq 0.001$. Means followed by $n s$ do not represent significance differences at $\mathrm{P} \geq 0.05$.

\begin{tabular}{lccccccccccc}
\hline & SI & LA & SLA & SD & OD & SL & SW & SA & SC & OA & LT \\
\hline SI & - & $-0.423^{*}$ & $-0.018^{\mathrm{ns}}$ & $0.767^{*} *$ & $0.500^{*}$ & $0.179^{\mathrm{ns}}$ & $0.344^{\mathrm{ns}}$ & $0.318^{\mathrm{ns}}$ & $0.090^{\mathrm{ns}}$ & $-0.571^{* * *}$ & $-0.236^{\mathrm{ns}}$ \\
$\mathrm{LA}$ & - & - & $0.315^{\mathrm{ns}}$ & $-0.736^{* * *}$ & $-0.769^{* * *}$ & $0.033^{\mathrm{ns}}$ & $-0.398^{*}$ & $-0.223^{\mathrm{ns}}$ & $0.273^{\mathrm{ns}}$ & $0.744^{* * *}$ & $-0.162^{\mathrm{ns}}$ \\
$\mathrm{SLA}$ & - & - & - & $-0.415^{*}$ & $-0.548^{*}$ & $-0.203^{\mathrm{ns}}$ & $0.171^{\mathrm{ns}}$ & $-0.010^{\mathrm{ns}}$ & $-0.130^{\mathrm{ns}}$ & $0.538^{* *}$ & $-0.399^{\mathrm{ns}}$ \\
$\mathrm{SD}$ & - & - & - & - & $0.937^{*}$ & $0.035^{\mathrm{ns}}$ & $0.221^{\mathrm{ns}}$ & $0.149^{\mathrm{ns}}$ & $-0.027^{\mathrm{ns}}$ & $-0.956^{* * *}$ & $0.029^{\mathrm{ns}}$ \\
$\mathrm{OD}$ & - & - & - & - & - & $-0.041^{\mathrm{ns}}$ & $0.115^{\mathrm{ns}}$ & $0.038^{\mathrm{ns}}$ & $-0.086^{\mathrm{ns}}$ & $-0.987^{* * *}$ & $0.181^{\mathrm{ns}}$ \\
$\mathrm{SL}$ & - & - & - & - & - & - & $0.300^{\mathrm{ns}}$ & $0.799^{*} *$ & $0.309^{\mathrm{ns}}$ & $-0.007^{\mathrm{ns}}$ & $-0.217^{\mathrm{ns}}$ \\
$\mathrm{SW}$ & - & - & - & - & - & - & - & $0.813^{* *} *$ & $-0.326^{\mathrm{ns}}$ & $-0.086^{\mathrm{ns}}$ & $-0.340^{\mathrm{ns}}$ \\
$\mathrm{SA}$ & - & - & - & - & - & - & - & - & $-0.019^{\mathrm{ns}}$ & $-0.049^{\mathrm{ns}}$ & $-0.343^{\mathrm{ns}}$ \\
$\mathrm{SC}$ & - & - & - & - & - & - & - & - & - & $-0.043^{\mathrm{ns}}$ & $-0.020^{\mathrm{ns}}$ \\
$\mathrm{OA}$ & - & - & - & - & - & - & - & - & - & - & $-0.160^{\mathrm{ns}}$ \\
$\mathrm{LT}$ & - & - & - & - & - & - & - & - & - & - & - \\
\hline
\end{tabular}


a reduction in leaf size through diminishing cell growth, more evident in ordinary epidermal cells than the guard-cells encompassing stomatal complexes. This had been reported previously in Betula pendula (Eichelmann et al., 2004) and Populus tremuloides (Riikonen et al., 2008).

Both stomatal density and index generally decrease with diminishing light intensity (Pallardy and Kozlowski, 1979). The effect of light conditions on the stomatal density and index is one of the most intensively studied environmental controls in stomatal development (Woodward, 1998; Woodward and Kelly, 1995). According to Miyazawa et al. (2006), the shading of leaves brings about a significant reduction in the epidermal cell density. It is believed that the increase in stomatal and epidermal cell densities must be due to an increase in stomatal initiation, as well as epidermal cell divisions, during the early stages of leaf growth. Nevertheless, the size of the stomata (including the guard-cell and pore), besides guard-cell length and width, do not change at all, as was also observed in Xanthosoma sagittijolium, Manihot esculenta and Dioscorea esculenta (Onwueme and Johnston, 2000). This suggests that stomatal differentiation is regulated by another physiological mechanism than that which determines epidermal cell division and/or expansion. As a result of this complex interaction between cell growth and differentiation, fullsun conditions induced an increase in SI in small leaves. Apart from the reduced SD and SI, no changes were found in stomatal characteristics under any of the sun conditions. Salisbury (1927) drew attention to changes in stomatal frequency due to a number of environmental factors affecting growth, and proposed eliminating cellsize from measurement criteria, introducing instead his 'stomatal index'. According to Salisbury, the stomatal index is fairly constant for a particular species. However this is inconsistent with the findings from the present study.

Changes in SI in plants submitted to different light regimes is well documented (Miyazawa et al., 2006; Royer, 2001), although, information on the cause is absent. In this study, it is shown that shading promotes an increased in ordinary cell-area (35\%) and a reduction in density (20\%). Table 2, show a significant $(\mathrm{P} \leq 0.05)$ positive correlation of SI with OD $\left(\mathrm{R}^{2}=0.500\right)$, whereas, on the other hand, a negative correlation $(\mathrm{P} \leq 0.001)$ was observed with $\mathrm{OA}$ $\left(\mathrm{R}_{\mathrm{a}}^{2}=-0.571\right)$. Notwithstanding, SD or SI did not correlate with any of the stomatal characteristics studied in this work (Table 2), which is in disagreement with previous studies where SD changes were reflected in guard-cell dimensions (Ceulemans et al., 1995; Liao et al., 2005; Rahim and Fordham, 1991). Stomatal density changed to a higher degree through shading than did SI. The rise in leaf expansion was accompanied by a drop in SD, without any alteration in guard-cell dimensions, but with significant alterations in those of ordinary cells. In the present work, it is shown that the plasticity of ordinary epidermal cells is high, contrary to the guard-cells. This suggests that stomata differentiation is regulated by a different physiological mechanism than that observed in ordinary epidermal cells, i.e. plasticity is different in the development of guard-cells and other epidermal cells.

Concentration of $\mathrm{CO}_{2}$ in the substomatal cavity of photosynthesising $\mathrm{C}_{3}$ leaves is lower than in the air. Furthermore, $\mathrm{CO}_{2}$ diffuses into the leaf along the gradient in $\mathrm{CO}_{2}$ concentration. Stomatal density is an important ecophysiological parameter that affects gas exchange, stomatal conductance $\left(g_{s}\right)$ and instantaneous water use efficiency $\left(W_{\mathrm{W}}\right.$ ). Therefore, if plants show long-term anatomical leaf adjustments to different sun levels, $\mathrm{WUE}_{\mathrm{i}}$ could be altered by stomatal density and/or dimensions (Ceulemans et al., 1995). The increase in SI or SD could lead to a rise in $\mathrm{CO}_{2}$ flow into leaves, although the higher $g_{\mathrm{s}}$, as a result of higher evaporative demand in long shoot leaves, probably counteracts this effect to some extent (Riikonen et al., 2008). However, Paoletti and Gellini (1993) suggested that the main factor reducing $g_{\mathrm{s}}$ and improving $\mathrm{WUE}_{\mathrm{i}}$ is not the alteration in stomatal density or stomatal pore-area, but a reduction in the stomatal opening. In agreement with Miyazawa et al. (2006), there was but a low correlation of both net photosynthesis and transpiration with the stomatal index, although a distinct one with $g_{s}$. An increase in SI or SD promote a lowering in overall stomatal resistance $\left(1 / g_{\mathrm{s}}\right)$ which compensates for the increase in resistance to $\mathrm{CO}_{2}$ flow into the mesophyll (Liao et al., 2005; Miyazawa et al., 2006; Radoglou and Jarvis, 1990; Woodward, 1998). In this sense, an increase in SD or SI, coupled with the increased availability of light in full-sun leaves, can promote photosynthesis, although the increase in WUE $_{\mathrm{i}}$ (Bergmann, 2004; Waggoner and Zelitch, 1965; Woodward, 1987; Zhao et al., 2006), would mean a possible rise in the production of dry matter - e.g. Cinnamomum camphora (Zhao et al., 2006) and Triticum aestivum (Liao et al., 2005).

\section{Conclusion}

In the present work, it was shown that shading affects both stomatal density and stomatal index, although to a lesser extent in the latter. These different alterations in the SD and SI make the latter a more applicable tool in taxonomic inferences, whereas the former is more adequate in indicating morphological plasticity in those leaves subjected to different light regimes. As seen in this study, variations in SD and SI can be attributed to differences in plasticity of the ordinary epidermal cells, and not to guard-cells, as previously reported.

\section{Abbreviation List}

Abscisic acid (ABA); formaldehyde : acetic acid : ethanol (5:5:90 v/v) (FAA); instantaneous water use efficiency $\left(\mathrm{WUE}_{\mathrm{i}}\right)$; ordinary epidermal cell area (OA); ordinary epidermal cell density (OD); specific leaf area (SLA); stomatal area (SA); stomatal complexes areas (SC); stomatal conductance $\left(g_{\mathrm{s}}\right)$; stomatal density (SD); stomatal index $(\mathrm{SI})$; stomatal resistance $\left(1 / g_{\mathrm{s}}\right)$ 
Acknowledgements - The authors would like to thank the Conselho Nacional de Desenvolvimento Científico e Tecnológico (CNPq) and Fundação de Amparo a Pesquisa do Estado de Minas Gerais (FAPEMIG) for financial support for this research. Special thanks are also due to Mrs. Gilmara Martini Pompelli for logistical support in the figures and tables, and Dra. Jarcilene Silva de Almeida Cortez and Prof. Ramon Arthur Clark for revising the manuscript and help in correcting and revising the English text.

\section{References}

BERGMANN, DC., 2004. Integrating signals in stomatal development. Current Opinion in Plant Biology, vol. 7, p. 26-32.

CEULEMANS, R., PRAET, LV. and JIANG, XN., 1995. Effects of $\mathrm{CO}_{2}$ enrichment, leaf position and clone on stomatal index and epidermal cell density in poplar (Populus). New Phytologist, vol. 131, p. 99-107.

DE BARY, A., 1877. Vergleichende anatomie der vegetationsorgae der Phanerogamen und Farne. Leipzig: W. Engelmann, 344 p.

DICKINSON, WC., 2000. Integrative Plant Anatomy. San Diego: Harcourt Academic Press, 533 p.

EICHELMANN, H., OJA, V., RASULOV, B., PADU, E., BICHELE, I., PETTAÍ, H., TULVA, I., KASPAROVA, I., VAPAAVUORI, E. and LAISK, A., 2004. Photosynthetic parameters of birch (Betula pendura Roth) leaves growing in normal and $\mathrm{CO}_{2}$ and $\mathrm{O}_{3}$ enriched atmospheres. Plant Cell and Environment, vol. 27, p. 479-495.

EPSTEIN, E., 1972. Mineral nutrition of plants: principles and perspectives. New York: John Wiley \& Sons, 412 p.

FAHL, JI., CARELLI, MLC., VEGA, J. and MAGALHÃES, AC., 1994. Nitrogen and irradiance levels affecting net photosynthesis and growth of young coffee plants (Coffea arabica L.). Journal of Horticultural Science, vol. 69, p. 61-169.

FAHN, A., 1990. Plant Anatomy. $2^{\text {th }}$ ed. Oxford: Butterworth Heinemann, $588 \mathrm{p}$.

FRANKS, PJ. and FARQUHAR, GD., 2001. The effect of exogenous abscisic acid in stomatal development, stomatal mechanisms, and leaf gas exchange in Tradescantia virginiana. Plant Physiology, vol. 125 , p. $935-942$.

JOHANSEN, DA., 1940. Plant microtechnique. $3^{\text {rd }}$ ed. New York: Paul B. Hoeber, Inc., 790 p.

KAKANI, VG., REDDY, KR., ZHAO, D. and MOHAMMED, AR., 2003. Effects of ultraviolet-B radiation on cotton (Gossypium hirsutum L) morphology and anatomy. Annals of Botany, vol. 91, p. 817-826.

LAKE, JA., QUICK, WP., BEERLING, DJ. and WOODWARD, EI., 2001. Signals from mature to new leaves. Nature, vol. 411, p. 154.

LIAO, J.-X., CHANG, J. and WANG, G.-X., 2005. Stomatal density and gas exchange in six wheat cultivars. Cereal Research Communications, vol. 33, p. 719-726.

MAUSETH, JD., 1988. Plant anatomy. San Francisco: Benjanmin Cummings.

MELO DE PINNA, GFA., KRAUS, JE. and MENEZES, NL., 2002. Morphology and anatomy of leaf mine in Richterago riparia Roque (Asteraceae) in the campos rupestres of Serra do Cipó, Brazil. Brazilian Journal of Biology, vol. 62, p. 179-185.

MIYAZAWA, S.-I., LIVINGSTON, NJ. and TURPIN, DH., 2006. Stomatal development in new leaves is related to the stomatal conductance of mature leaves in poplar (Populus trichocarpa x P. deltoides). Journal of Experimental Botany, vol. 57, p. 373-380.

ONWUEME, IC. and JOHNSTON, M., 2000. Influence of shade on stomatal density, leaf size and other leaf characteristics in the major tropical root crops, tannia, sweet potato, yam, cassava and taro. Experimental Agriculture, vol. 36, p. 509-516.

PALLARDY, SG. and KOZLOWSKI, TT., 1979. Frequency and length os stomata of 21 Populus clones. Canadian Journal of Botany, vol. 57, p. 2519-2523.

PANDEY, S., KUMAR, S. and NAGAR, PK., 2003. Photosynthetic performance of Ginkgo biloba L. grown under high and low irradiance. Photosynthetica, vol. 41, p. 505-511.

PAOLETI, E. and GELLINI, R., 1993. Stomatal density variation in beech and holm oak leaves collected over the last 200 years. Acta Oecologica, vol. 14, p. 173-178.

RADOGLOU, KM. and JARVIS, PG., 1990. Effects of $\mathrm{CO}_{2}$ enrichment on four poplar clones. II. Leaf surface properties. Annals of Botany, vol. 65, p. 627-632.

RAHIM, MA. and FORDHAM, R., 1991. Effect of shade on leaf and cell size and number of epidermal cells in garlic (Allium sativum). Annals of Botany, vol. 67, p. 167-171.

RIIKONEN, J., KETS, K., DARBAH, J., OKSANEN, E., SÔBER, A., VAPAAVUORI, E., NELSON, N., KUBISKE, M. and KARNOSKY, D., 2008. Carbon gain and bud physiology in Populus tremuloides and Betula papyrifera grown under long-term exposure to interacting elevated $\mathrm{CO}_{2}$ and $\mathrm{O}_{3}$. Tree Physiology, vol. 28, p. 243-254.

ROYER, DL., 2001. Stomatal density and stomatal index as indicators of paleoatmospheric $\mathrm{CO}_{2}$ concentration. Review of Palaeobotany \& Palynology, vol. 114, p. 1-28.

SALISBURY, EJ., 1927. On the causes and ecological significance of stomatal frequency with special reference to the woodland flora. Philosophical Transactions of the Royal Society of London B Biological Sciences, vol. 216, p. 1-65.

SCHOCH, P.-G., ZINSOU, C. and SIBI, M., 1980. Dependence of the stomatal index on environmental factors during stomatal differentiation in leaves of Vigna sinensis L. 1. Effect of light intensity. Journal of Experimental Botany, vol. 31, p. 1211-1216.

SERNA, L. and FENOLI, C., 2000. Stomatal development in Arabidopsis: how to make a functional pattern. Trends in Plant Science, vol. 5, p. 458-460.

WAGGONER, PE. and ZELITCH, I., 1965. Transpiration and the stomata of leaves. Science, vol. 150, p. 1413-1420.

WARREN, CR., LÖW, M., MATYSSEK, R. and TAUSZ, M., 2006. Internal conductance to $\mathrm{CO}_{2}$ transfer of adult Fagus sylvatica: Variation between sun and shade leaves and due to free-air ozone fumigation. Environmental and Experimental Botany, vol. 59, p. 130-138.

WOODWARD, FI., 1987. Stomatal numbers are sensitive to increase in $\mathrm{CO}_{2}$ from pre-industrial levels. Nature, vol. 327, p. 617-618.

-., 1998. Do plants really need stomata? Journal of Experimental Botany, vol. 49, p. 471-480.

WOODWARD, FI. and KELLY, CK., 1995. The influence of $\mathrm{CO}_{2}$ concentration on stomatal density. New Phytologist, vol. 131, p. 311-327.

ZHAO, X., YANG, Y., SHEN, Z., ZHANG, H., WANG, G. and GAN, Y., 2006. Stomatal clustering in Cinnamomum camphora. South African Journal of Botan, vol. 72, p. 565-569. 